\title{
Modeling Cultural Content for Outreach Programs in Marginalized Communities in Asia: A Case Study of South Korea
}

\author{
Sung Jin Lee ${ }^{1} \&$ Jae-Eun $\mathrm{Oh}^{2}$ \\ ${ }^{1}$ Division of Design, Major of Cartoon and Animation, Baekseok Culture University, South Korea \\ ${ }^{2}$ School of Design, The Hong Kong Polytechnic University, China \\ Correspondence: Jae-Eun Oh, School of Design, The Hong Kong Polytechnic University, Hung Hom, Kowloon, \\ Hong Kong (SAR), China. Tel: 852-2766-5451. E-mail: jae.oh@ polyu.edu.hk
}

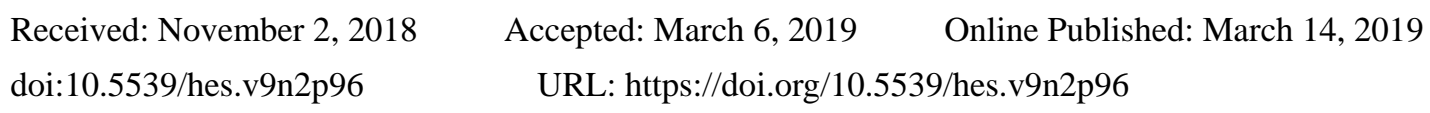

\begin{abstract}
Wherever quality of life continues to improve, people turn to cultural and artistic pursuits to enhance their life experience. Hence, cultural and art education is encouraged in museums, galleries, and schools for public benefit and enjoyment regardless of differing social classes. Cultural content has developed since the beginning of culture itself, and education related to this content is crucial as it can improve public perspectives. However, many culturally alienated groups still exist due to financial difficulties, disabilities, or living in remote areas, and they lack fair opportunities to enjoy culture and art. The polarization between these groups and culturally-benefited classes continues to increase.

Outreach programs have been conducted by museums and galleries as 'visiting classes' for those who find it difficult to visit traditional venues. Using Dewey's educational philosophy and four different case studies, this study provides an in-depth examination of outreach programs and suggests a model for Asian countries by focusing on South Korea. The findings seek to aid ongoing educational efforts to create long-term effects for the public's benefit.
\end{abstract}

Keywords: cultural outreach programs, culturally alienated groups, cultural content education, cartoon bus

\section{Introduction}

A nation's cultural policy is considered a crucial tool for political leadership, created with the intention of shaping one common cultural identity across various groups within the country (Bradley, 1998; Burgi-Golub, 2000). Specific to South Korea, approaches to cultural policy have evolved since the establishment of the First Republic in 1948 (Yim, 2002). Yersu Kim (1976) observes that in spite of political leadership changes and the division of Korea, the construction of cultural identity has remained a key fixture of Korea's postcolonial government agenda. Contemporary policies have been put in place to dampen identity politics that question the South Korean identity. In order to cultivate a Korean national identity that is in line with the government's political agenda, cultural policies administered since 1948 have ensured that culture reaches the masses across all demographics.

In contemporary South Korea, the government has encouraged the enjoyment of culture by establishing cultural centers in otherwise culturally isolated areas. It also provides opportunities for engagement in cultural activities to traditionally alienated classes within society (Kim, 1976; Yim, 2002), including low-income families and people with disabilities. However, in any discussion of cultural immersion and fostering a common national identity, we must note the importance of creating relevant cultural content. Cultural content essentially involves relevant tangible consumable content (e.g. films, videos, radio, music, arts and crafts) that is carefully organized and packaged under a policy-directed cultural identity narrative. Thus, this article views cultural content as a fundamental building block of culture, while understanding identity narrative and its production as the process of drawing upon "a stock of already existing cultural elements from the reservoirs of lived culture or from the already public fields of discourse" (Johnson, 1986, p. 38).

Unlike culture itself, cultural content is a one-way initiative (Pratt, 1992). Furthermore, cultural content administered solely by the government can potentially be viewed as propaganda and may incite backlash. It would be ignorant to assume that culture itself is solely rooted in sociopolitical endeavors supported by the 
government, however. As observed by Yeong-Guen Jung (2009), culture is rooted in human nature and influenced by tradition and society. Seung-Hwan Shin (2007) adds that cultural education is imperative, as it creates opportunities for self-understanding through experience, and that as a process it is not stagnated in time. Thus, education enables content creators to understand the policy and techniques required for content creation in relation to tradition and personal histories (Jung, 2009).

Using this understanding of cultural policy and its relationship to cultural identity construction, particularly with regard to South Korea, this article is concerned with how facets of cultural policy and cultural content education can be harnessed to bridge gaps between both 'high' and 'low' culture, as well as the gaps between different social strata in contemporary South Korea. Currently, there is little to no academic research that focuses on the specifics of culture and marginalized communities in relation to education and content creation from the Asian perspective.

For this article, marginalized communities will be referred to as the alienated classes: those who are unable to encounter cultural content due to financial issues, disability, lack of information, or lack of interest. This class also includes children who are institutionalized, senior citizens, low-income families, migrant workers, foreign spouses, rural area residents, refugees, and people in correctional institutions. These people are alienated from society, either by circumstance or geography, and thus their access to art and culture is restricted to their own or neighboring communities. Those who live in remote areas are also neglected in terms of direct access to the arts and culture and can only experience culture indirectly through the internet and digital devices.

Noting that cultural education is progressive and influenced by changes in society, we will use qualitative research methods alongside John Dewey's framework of Progressive Education to evaluate and structure a cultural outreach program for marginalized communities in South Korea. To achieve this aim, we propose the following research questions:

(1) Who are the marginalized in South Korea and how are they defined in society?

(2) What are the elements and characteristics of Dewey's Progressive Education model that can inform the establishment of a cultural outreach program for marginalized communities specific to South Korea?

\section{Literature Review}

\subsection{Defining Culture: A Changing Concept for Alienated Communities}

The definition of 'culture' has been deeply contested (Merry, 1998). Historically, culture was a largely European concept, a model that allowed for the segregation of 'civilized' persons from the lower classes. Echoing this perspective was the Germanic notion of Kultur as juxtaposed with Zivilisation: a claim of separation between the German bourgeoisie and aristocrats of other nations in the face of a globalizing aristocratic language and custom (Elias, 1939). Thus, culture can be understood as historically produced, constantly contested within structures of power, and rooted in practices, habits, and symbols that cater to the dominant psychographic (Merry, 1998; Vincent, 1990).

We can observe the idea of culture as bound by a similar binary across time: the establishment of a prevailing practice juxtaposed against practices of groups outside the dominant culture (or sub-culture). However, this perception of culture in contemporary society has its shortcomings; it blinds us to a culture's potential flaws and suggests that culture is a one-way street that seeks only to segregate. Some of theories of culture have addressed this inadequacy. John and Jean Comaroff's Ethnography and the Historical Imagination (1992) examines the historical roots of culture and culture content creation, with additional observations on contemporary society. They suggest that culture is not a closed system, but rather a fluid cycle that allows for multiple and contested meanings to exist.

In addition, the traditional definition of culture fails to acknowledge the presence of cultural contact zones and potentials for 'transculturation', as Mary Louise Pratt observed in her publication Imperial Eyes: Travel Writing and Transculturation (1992). Pratt furthers Comaroff and Comaroff's (1992) theory that culture, and in turn its creation, functions as a fluid and open system, describing cultures as fields of interaction. These fields act as social spaces where disparate cultures "meet, clash, and grapple" with each other, often in highly asymmetrical relations of domination and subordination that can be determined by class, geography, and/or economic circumstance (Pratt, 1992).

Noting the asymmetrical relationship between access to culture and a group's socioeconomic status, this article takes an approach to culture adapted from Pratt (1992) and Comaroff and Comaroff (1992). Given our target demographic of alienated classes, Pratt's definition of culture clearly describes potential clashes of cultural access and understanding between the dominant and alienated classes. Comaroff and Comaroff (1992) 
supplement this observation of asymmetrical relations between classes, suggesting that this fluid and open system nurtures the existence of multiple and contested meanings of culture and its content.

\subsection{Cultural Policy and Identity Politics: The South Korean Perspective}

Interpretations of culture and identity are deeply entrenched in the Korean peninsula's history. Issues pertaining to identity and a distinctively Korean culture first arose from the ongoing discontinuity and contestation over Korea's traditional and contemporary culture. Present-day South Korean culture is influenced by a melting pot of colonial and postcolonial experiences: trauma, cultural erosion, and distortion stemming from Japanese colonialism (1910-1945); the division of Korea (1945-present); the Korean War (1950-1953), which saw the rapid and indiscriminate influx of Western culture through the presence of American troops; and rapid modernization, following the spark of industrialization in the 1970s. In essence, what we see of Korean traditional culture today is an amalgamation of various sociopolitical experiences largely giving way to Westernization.

In spite of the aggressive Westernization and threats to Korean culture throughout the nation's tumultuous history, the notion of a Korean identity (or Korean-ness) remains central to rhetoric of modern cultural policy. This identity is one deeply rooted in pragmatism. It is also important to highlight the influence of Confucianism on the arts; the virtues of Confucianism are deeply embedded, with culture seen as a vehicle for cultivating morality in the masses. As pointed out by Haksoon Yim (2002), despite the division of the Korean peninsula in 1945, the notion of Han minjok (meaning 'Korean people' or 'Koreans') and the influence of Confucianism have remained "remarkably homogeneous" (p. 38). This cultural nationalism remains the cornerstone of Korean cultural policy today. Park (2017) postulates that Korean cultural education has accelerated much faster under the influence of western cases, and it has come to realization that culture-art education should not be separated from the educational policies for the effective result. It is because (1) culture-art education is one of the methods to solve the social problems, (2) it also offers us the rewarding satisfaction for the emotional stability, and (3) it induces the change an outlook on the world by experiencing cultural diversity (Park, 2017).

Yet therein lies the contradiction between Korea's cultural policies and its mass appeal. While over the years the nation's cultural policies have sought the propagation of Korean culture across the mainstream demographic, the reach of cultural education and content in society has been observed to be determined by a person's social status and access to culture and heritage sites. In essence, while Korean culture and identity is strong, there is an asymmetrical relationship between cultural education and content creation across the different social classes (Comaroff \& Comaroff, 1992). In spite of these observations, there are currently no known scholarly articles that address this issue of accessibility to cultural education and content creation in the English language or from the Asian perspective. This article hopes to fill these gaps and provide a pedagogical approach toward the creation of outreach programs for marginalized communities in Asia.

\subsection{Establishing a Framework: John Dewey's Philosophy of Progressive Education}

With South Korean cultural policy so deeply rooted in pragmatism, this study adapts John Dewey's Philosophy of Progressive Education in order understand the relationship between cultural education and content creation in alienated communities in South Korea. Dewey's Philosophy, established in the early 1930s, proposed that schools were not simply facilities that fulfilled the role of traditional education, but rather agencies that sought to create a semblance of society before children experienced life outside the educational institution. Schools must be conceived "as agencies for bringing home to the child some of the primal necessities of community life," and "as instrumentalities through which the school itself shall be made a genuine form of active community life, instead of a place set apart in which to learn lessons" (Dewey, 1956, p. 12).

Dewey's Philosophy of Progressive Education suggests that pedagogical methods harnessed by schools cannot be abstract or divorced from life itself. Rather, the school functions as a miniature community that prepares children for the occupations of larger society. In the context of art and cultural production, Dewey considers art to be an aesthetic experience, arguing that this experience can help us find meaning and reach self-realization by improving our quality of life. As illustrated in Figure 1, Dewey suggests that the interaction between an individual and their environment determines the values behind their interactions with the environment, as well as nurturing their instrumental intelligence. This in turn creates education through practical experiences. 


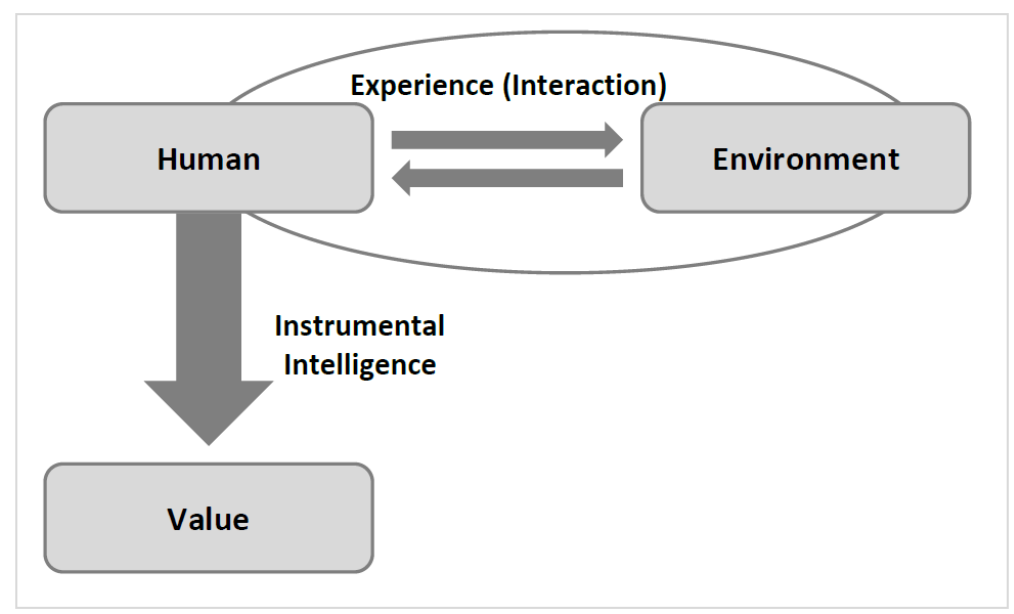

Figure 1. Framework of John Dewey's Philosophy of Progressive Education

A key aspect that drives this philosophy is the notion of pragmatism. Dewey argues that there is a need for education to be pragmatic and democratic; he assumes all parties are equal and share the aim to create a social consciousness amongst learners (Dewey, 1916). Historically, the curriculum harnessed by Dewey consisted of three elements: Knowledge, Intellect and Recreation (Dewey, 1956). In theory, combining these three aspects allows education to move beyond formal means, accepting that education seeks to influence life, personal growth, and ultimately, social progress.

In contextualizing Dewey's pedagogical philosophy to contemporary education, we see a need for current traditional education structures to be remodeled using elements from Dewey's research. Most importantly: uprooting the notion that the educational experience is contained within the school environment and understanding the need for education to be embedded into daily life. This would enable students to consistently allow their experiences to shape their education and social consciousness.

\subsection{Cultural Education and Outreach for Alienated Communities}

In addition to formal education, Dewey's Philosophy of Progressive Education has the potential to extend to cultural and art education. Scholars have debated the definition and need for cultural and art education in various societies, addressing issues of opportunity and exclusion of alienated groups from mainstream cultural narratives (Zeller, 1989; Sandell, 2003). In an article detailing the importance of the humanities in art education, Terry Zeller (1989) suggests that cultural and art education be defined as the provision of opportunities for cultural benefit to the public, with an emphasis on the practicality of content education and the need for such programs to cater to the different social classes in a democratic fashion. Similarly, Sandell (2003) proposes the need for communication opportunities to be presented to the alienated classes, stressing that cultural education be harnessed to narrow the gap between mainstream and alienated communities to prevent social exclusion. These discussions are similar to the foundation of Dewey's Philosophy of Progressive Education: the need for education to be pragmatic and democratic, and to benefit or have an influence on the individual's life (Dewey, 1956).

However, it must be noted that these scholars have centered discourse within a Western context. In extending this core framework to Asia, this paper uses South Korea and cultural policy efforts in establishing outreach programs to bridge the gap between mainstream and alienated communities in this society. However, given the shortage of research and existing programs within the Asian sphere, this paper will also look into Australian and American case studies of visiting programs for those who live in remote areas or have mobility difficulties. We will then use our observations from these Western case studies to inform potential future outreach programs in South Korea.

The South Korean government first initiated outreach programs in the late 1980s for culturally alienated areas: military camps and rehabilitation centers for the elderly and disabled. One of the first such outreach programs, or 'visiting' programs, was established in 1989 by the South Korean Ministry of Culture. Focusing on the concept of 'visiting' museums and galleries, teams brought these traditionally fixed, admission-charging institutions to alienated communities with the aim of sharing information and knowledge (Kim, 2010). This provided members 
of alienated communities with an equal opportunity to experience culture in their daily lives. Ongoing support from the government's cultural policy has allowed these 'visiting' cultural movements to increase since their inception in the 1990s, improving access to the arts and culture for alienated classes (Woo, 2005). Today, it is apparent that 'visiting programs' can provide opportunities for people no matter where they live. However, these outreach programs focus largely on and are limited to material from galleries and museums (e.g. fine art, traditional Korean pottery, paintings). While it is important for alienated communities to gain an understanding of cultural history, there is also a preconceived notion that the arts only cater to adults. As such, this paper will focus on outreach programs aimed at alienated classes that comprise content catered towards children and teenagers. These include media such as animation, cartoons, and games.

\section{Research Methodology}

\section{Case studies}

This study adopts a qualitative research method to examine different cases of diverse organizations' outreach programs and activities and how Asian cultural outreach programs could be designed. We chose case studies as our primary method of analysis to gain a detailed understanding of how various government bodies, museums, and galleries have successfully operated outreach programs in their communities in order to evaluate the effectiveness of an outreach model for South Korea. As for secondary research, we reference The Fun Art Journey (The Korea Lottery Commission), Virginia MOCA in the USA, and the Australian Museum in Sydney, Australia, as all three have integrated standard school curricula into their outreach programs and utilize a mobile service for their audiences who live in remote areas. Lastly, the research includes participant observation by the second author, also one of the leaders of the 'Manhwa Bus' program which provides a mobile service, in the discussion section.

We aligned the aforementioned case studies along four key categories: programs that diffuse art into daily life; location-specific programs that align with school curricula; programs that restructure learning experiences; and programs that seek to build social consciousness. The outreach programs we discuss will be analyzed under the framework of Dewey's Philosophy of Progressive Education, with the aims of 1) understanding the relevance of Dewey's observations in today's society, and 2) potentially establishing a preliminary model for cultural outreach programs in Asia.

\subsection{The Fun Art Journey: Diffusing Art into Daily Life}

Defined by the Oxford Dictionary as "an organization's involvement with or influence in the community, especially in the context of religion or social welfare" (n.d.), cultural outreach programs that seek to permeate the daily lives of individuals in alienated communities are the most pertinent forms of cultural outreach activities in South Korea. This fulfills Dewey's philosophy that education should go beyond the classroom and influence lives.

One key case study is The Fun Art Journey, run by the Korea Lottery Commission under the Ministry of Strategy and Finance. The Fun Art Journey was established as an initiative under their cultural welfare plan in order to ensure transparency in the governance of funds from the lottery business and to reach out to culturally marginalized communities.

Table 1. Program categories offered by The Fun Art Journey (2004-2015)

\begin{tabular}{ll}
\hline Literature & Literature concert, Creativity experience, Oral storytelling, Performance related to literature \\
\hline Visual Art & Art show, Creative participation \\
The Play & Play, Musical, Mime, Non-verbal performance, Puppet show \\
Dance & Korean traditional dance, Contemporary dance, Ballet \\
Music & Opera, Vocal music, Orchestral music, Chamber music, Children's song, Chorus, Vocal ensemble \\
Traditional Performing Arts & Korean traditional music, Korean traditional opera, National theatrical performance, Madangguk: \\
& One of Korea's traditional performances, Traditional Korean masked dance \\
Mixed Genre Arts & Programs comprising different types of art \\
General Arts & B-Boy dance, Magic, Circus, Concert, Comedy \\
\hline
\end{tabular}

Focusing on Literature and the Performing Arts (Table 1), the program has provided cultural opportunities for remote areas, military camps, rehabilitation centers, people with disabilities, senior citizens, and low-income families. A total of 2,083 cultural art programs were presented over an 11-year period (2004-2015). Independent arts organizations pitch their programs to a panel chosen by The Korean Lottery, and selected programs tour South Korea from April to November. The chosen programs are largely interactive in nature and build on themes 
that are universally understood.

Table 2. The Fun Art Journey's Program for 2016

\begin{tabular}{|c|c|c|c|c|}
\hline Name of Program & $\begin{array}{l}\text { Name of } \\
\text { Art Organization }\end{array}$ & Genre & Venue & $\begin{array}{l}\text { Date of } \\
\text { Performance }\end{array}$ \\
\hline $\begin{array}{l}\text { Fusion: Korean Traditional Music } \\
\text { with Nanta 'The Sound of Light' }\end{array}$ & Wa Musical Ground & Theatre & $\begin{array}{l}\text { Hopyeong-Dong, } \\
\text { Local community center }\end{array}$ & Oct 1st, 2016 \\
\hline Let's Play in the New World & NolSae, Playgroup & Traditional Art & ChoJeon Village & Oct 1st, 2016 \\
\hline $\begin{array}{l}\text { The Fun Art Journey with the } \\
\text { Artist from Yeong-Eun Gallery }\end{array}$ & Yeong-Eun Gallery & Visual Arts & $\begin{array}{l}\text { Gwangju City, } \\
\text { Senior welfare center }\end{array}$ & Oct 1st, 2016 \\
\hline $\begin{array}{l}\text { Travel to Time \& Space with } \\
\text { Pyeong Yang Performance Group }\end{array}$ & $\begin{array}{l}\text { Pyeong Yang } \\
\text { Performance Group }\end{array}$ & Mixed Genre Arts & Hanok Village, Mount Jiri & Oct 3rd, 2016 \\
\hline The Little Prince & Zero Point Motion & Dance & $\begin{array}{l}\text { Angel House, } \\
\text { Flower Village }\end{array}$ & Oct 3rd, 2016 \\
\hline Love Your Neighbor Music Concert & $\begin{array}{l}\text { People who Share } \\
\text { the Love of Songs }\end{array}$ & Music & $\begin{array}{l}\text { GyeongNam Headquarters, } \\
11 \text { Jang YuWolSan }\end{array}$ & Oct 4th, 2016 \\
\hline Literature Concert for the & Kick Kick & Literature & Gangneung High School & Oct 4th, 2016 \\
\hline Youth: 'Literature, Big Stride.' & $\begin{array}{l}\text { Cultural Organization } \\
\text { for the Youth }\end{array}$ & & & \\
\hline $\begin{array}{l}\text { Hip Hop, B-Boy Performance } \\
\text { for the Youth }\end{array}$ & $\begin{array}{l}\text { Association of Korean } \\
\text { Hip-Hop Culture }\end{array}$ & Dance & $\begin{array}{l}\text { Bugang Elementary } \\
\text { School }\end{array}$ & Oct 4th, 2016 \\
\hline
\end{tabular}

In 2016, a total of eight programs were chosen. As shown in Table 2, all programs were presented to audiences in community areas such as schools and community centers (e.g. Gangneung High School, Hanok Village). We should note that the programs featured contemporary art forms such as hip hop and B-boy dance performances. Rather than focusing solely on high art, programmers of The Fun Art Journey chose to emphasize friendly and straightforward themes, as well as cultural media such as dance and theatre. This ensured the greatest potential to narrow the cultural gap between mainstream and alienated communities. Making the arts and culture more accessible to these alienated communities, coupled with programs that seek interactivity between artists and audiences, creates the potential for individuals residing in alienated communities to pick up new art skills that they may be able to use in their daily lives. These might include learning how to make music and starting a band within their own community or learning to dance and setting up a local dance crew. This allows art to diffuse into their lives as they establish their own cultural activities.

\subsection{Collaboration with Traditional Pedagogy and Inculcating Social Consciousness}

In addition to outreach programs outside the traditional school framework, this paper also argues the need for outreach programs to be aligned and in collaboration with school curricula. This is necessary for individual growth, and in turn, the bridging of the cultural gap between alienated and mainstream communities. According to Dewey's early work (1916), schools are communal spaces that draw together communities from different social strata. They are key places where ideas of progressive education can be inculcated at an early age. In Dewey's Philosophy of Progressive Education, individuals should endeavor for consistent growth, along with the ability to shape their thoughts, words, and actions toward social change. However, progression cannot be accomplished without first training educators to keep their students motivated within the confines of a prescribed curriculum. Only then can educators help join the dots between schools and their communities.

Furthermore, this growth, as defined by Dewey (1897), is closely tied to the need for education to inculcate social consciousness, i.e., an individual's ability to discern and harness behaviors that take into consideration the wellbeing of society and the environment. Dewey believed that education is required in order for one to be able to understand the needs and appropriate etiquette of society. By adopting the correct (or in this case, socially acceptable) behaviors and cultural content, social progress can be achieved, creating fairer opportunities for the benefit of more people.

Taking the Asian context into consideration, and specifically South Korea, there have been little to no outreach programs of this type for alienated communities within the country. Existing outreach programs focus largely on creating experiential spaces and are of an ad-hoc nature, presenting culture and art experiences to these communities with little to no follow up either in or out of classrooms. Noting this, we will discuss three more case studies with active outreach projects from the USA and Australia, which will serve as benchmarks in order to draw insights that can potentially be applied to the contexts of South Korea and, eventually, Asia. 


\subsection{Tailoring Outreach Programs to Curricula}

To better understand how alienated classes can be introduced to the mainstream cultural narrative, we examined programs from two museums: the Virginia Museum of Contemporary Art (Virginia MOCA) in the USA, and the Australian Museum in Sydney, Australia. Programs from these two museums were chosen as reference studies for further outreach from the South Korean perspective, as they both align with standard school curricula and provide opportunities for alienated classes to engage with the arts at a smaller, more intimate level.

The arts outreach program at Virginia MOCA is provided to all public and private schools in Hampton Roads, Virginia. They offer ten courses for students between Grades 1 to 5 (5 to 11 years old). These programs emphasize integrating the principles of contemporary visual arts with the Virginia Standards of Learning curriculum goals across subjects such as English, Literature, History, and Mathematics. As described in Table 3, Virginia MOCA's programs are categorized according to grade level, providing a comprehensive curriculum that is tailored to the specific needs of students at each level.

Table 3. Breakdown of topics covered in each grade at Virginia MOCA's school outreach programs

\begin{tabular}{ll}
\hline Grade & Program Details \\
\hline First Grade & Undercover: Animal \& Human Shelters \\
Second Grade & Egypt: Gift of the Nile China: Old Place, New Face \\
Third Grade & Home Sweet Home: Animals \& Their Habitats It's Greek to Me Mali: Here to Timbuktu \\
Fourth Grade & Move it!: Electricity, Magnets \& Motors Virginians: First Landing and Beyond \\
Fifth Grade & Building with Light Freedom Rings \\
\hline
\end{tabular}

One essential element of Virginia MOCA's outreach program for visual arts is the inclusion of a family guest pass; as described in Table 4, this functions as a gesture of invitation to promote inclusivity within the arts community. In this program, students are not only able to learn themselves, but can extend this learning opportunity to their families. In the case of alienated communities, the family guest pass allows students from these communities to potentially return to the museum with friends and family from their community, putting their learning experience into practice by playing guide to their guests. This can narrow the gap between individuals from alienated communities and the mainstream cultural narrative.

Table 4. Process to Enroll for Outreach Programs at Virginia MOCA

\begin{tabular}{|c|c|}
\hline & Program Details \\
\hline $\begin{array}{l}\text { Pre-visit } \\
\text { materials }\end{array}$ & $\begin{array}{l}\text { Pre-visit materials are emailed to participating teachers before their visit. Faculty and administrative staff are } \\
\text { encouraged to book appropriate dates in advance. Participating schools must register for a minimum of two } \\
\text { back-to-back classroom visits. }\end{array}$ \\
\hline $\begin{array}{l}\text { MOCA } \\
\text { educator's visit }\end{array}$ & $\begin{array}{l}\text { MOCA outreach educators provide innovative, memorable lessons incorporating props, costumes, artifacts, hands-on } \\
\text { activities, creative movements, and so on. }\end{array}$ \\
\hline Free family pass & $\begin{array}{l}\text { Participating students will receive a guest pass to MOCA allowing them to return with up to five friends and family } \\
\text { members for free. }\end{array}$ \\
\hline $\begin{array}{l}\text { Cancellation } \\
\text { policy }\end{array}$ & $\begin{array}{l}\text { Outreach programs are in high demand with a long waiting list. In the case of a cancellation, schools need to notify the } \\
\text { museum via email at least one month before the scheduled class dates. }\end{array}$ \\
\hline
\end{tabular}

Source: http://www.virginiamoca.org/outreach-details

Similarly, the Australian Museum in Sydney, Australia also runs museum outreach programs in collaboration with school curricula (see Table 5). These outreach programs differ from that of Virginia MOCA, however, as they are not limited to the museum venue. Instead, they give participants the opportunity to go off-site (e.g. zoos, mountainous regions) to examine nature, including rocks, fossils, and flora and fauna unique to the continent (Table 5). Given Australia's vast geographical area, there are also options for the museum and schools to carry out activities through videoconferencing. This allows students and teachers, especially those in remote areas, to become more involved in and aware of urgent environmental issues, Australia's natural history, and its landscape. Outreach educational programs are selected from the education program in the table below. 
Table 5. Outreach programs at Australian Museum

\begin{tabular}{|c|c|}
\hline Program & Details \\
\hline Touring Exhibitions & $\begin{array}{l}\text { Increase visitation rate, encourage influx of new participating groups, and complement existing } \\
\text { attractions at different venues with the museum's natural history or cultural exhibitions: } \\
\text { - } \quad \text { Birds of paradise specimens } \\
\text { - Cultural objects } \\
\text { - Multimedia: Bird dance, festival, costume making and interviews }\end{array}$ \\
\hline Museum in a Box & $\begin{array}{l}\text { A program for educational institution across Australia. There are over } 30 \text { different boxes } \\
\text { containing real museum specimens, casts, artifacts, dioramas, images, DVDs, CDs, books, and resources. }\end{array}$ \\
\hline Museum 2 You & $\begin{array}{l}\text { A resource-rich, science-based community environmental education program for councils, } \\
\text { libraries, regional museums, community groups and organizations across New South Wales. }\end{array}$ \\
\hline Video Conferencing & $\begin{array}{l}\text { Schools can now access the Museum's collections and staff through an amazing } \\
\text { selection of video conferences. }\end{array}$ \\
\hline Evolution of Australia & Full-day programs run by educators from the Australian Museum, Royal Botanic Gardens \& \\
\hline Biota Study Days & Domain Trust, Taronga Conservation Society Australia, and North Coast Regional Botanic Garden. \\
\hline Bugwise & $\begin{array}{l}\text { Bugwise for Schools brings the world of invertebrates to the students, engaging them } \\
\text { in real science in local environments. }\end{array}$ \\
\hline
\end{tabular}

Source: http://australianmuseum.net.au

\subsection{Outreach Programs to Inculcate Social Consciousness}

Apart from education and standardized curricula, there is also the potential for outreach programs to aid in inculcating social consciousness. This aspect is pertinent to members of both mainstream and alienated communities, as it allows them to reflect upon themselves and understand each other's behaviors and attitudes. To contextualize this, the Museums Victoria in Australia provides a good case study for immigration issues by hosting a number of immigrants' stories on their website and promoting how museum outreach can help bridge gaps of understanding between these communities. In order to cater to alienated communities in remote areas, the Museums Victoria in Australia also has an outreach program with a mobile service that brings museum learning activities and object-based sessions to people who may find it difficult to visit one of the museum's venues. These include a mobile service for kindergarten students in remote areas; learning and reminiscing kits, where participants can use learning objects to study natural science and social history, or to enhance memory in elderly citizens; and mobile programs for adults in remote communities or who have been incarcerated. In essence, the museum brings learning to these alienated communities with the aim of decreasing their alienation, as well as increasing their awareness of potential social issues that affect both the mainstream and themselves. This awareness can then spark an interest and understanding of social consciousness that spills over to beyond their own alienated communities.

The above case studies of outreach at Western museums demonstrate active engagement with educational institutions and work to inculcate social awareness. By providing fair opportunities to everyone in society beginning with childhood, they allow many people to experience cultural enjoyment in various communities. A similar effort can be found in South Korea, where outreach programs use mobility to reach out to schools in remote areas. This case will be discussed in the next section.

\subsection{The Manhwa Bus: Restructuring the Continuous Learning Experience}

In addition to introducing learning as a way of life, Dewey's Philosophy of Progressive Education draws into consideration the need for pedagogical methods to be restructured to include continuous learning experiences that go beyond school classrooms. According to Dewey (1897), the key function of education is to change individual mindsets through the creation of experience for students. By introducing continuous experiential learning, teaching and learning become processes that intertwine and center on the key aim of achieving an interactive continuous process of growth and development in both educators and students.

To bring this into the South Korean context, we will discuss the case study of the Cartoon (or Manhwa) Bus. This will provide an Asian perspective for Dewey's Philosophy of Progressive Education and the need for continuous learning experiences to bridge the cultural gap between mainstream and alienated communities. Run and sponsored by NAVER, South Korea's leading internet content provider, and the Cultural Foundation, and led by legendary South Korean comic book artist Lee Hyun Se and his fellow artists, the Manhwa Bus is an arts-related outreach initiative targeted at teenagers since 2014. The key aim of the Manhwa Bus is to provide 
teenagers living in remote areas or other locations with the opportunity to practice drawing comics through experiential learning with industry professionals. In turn, the program restructures the learning process, taking it from rote learning in schools to an interactive learning and sharing of knowledge with professionals in the comics industry (Figure 2).
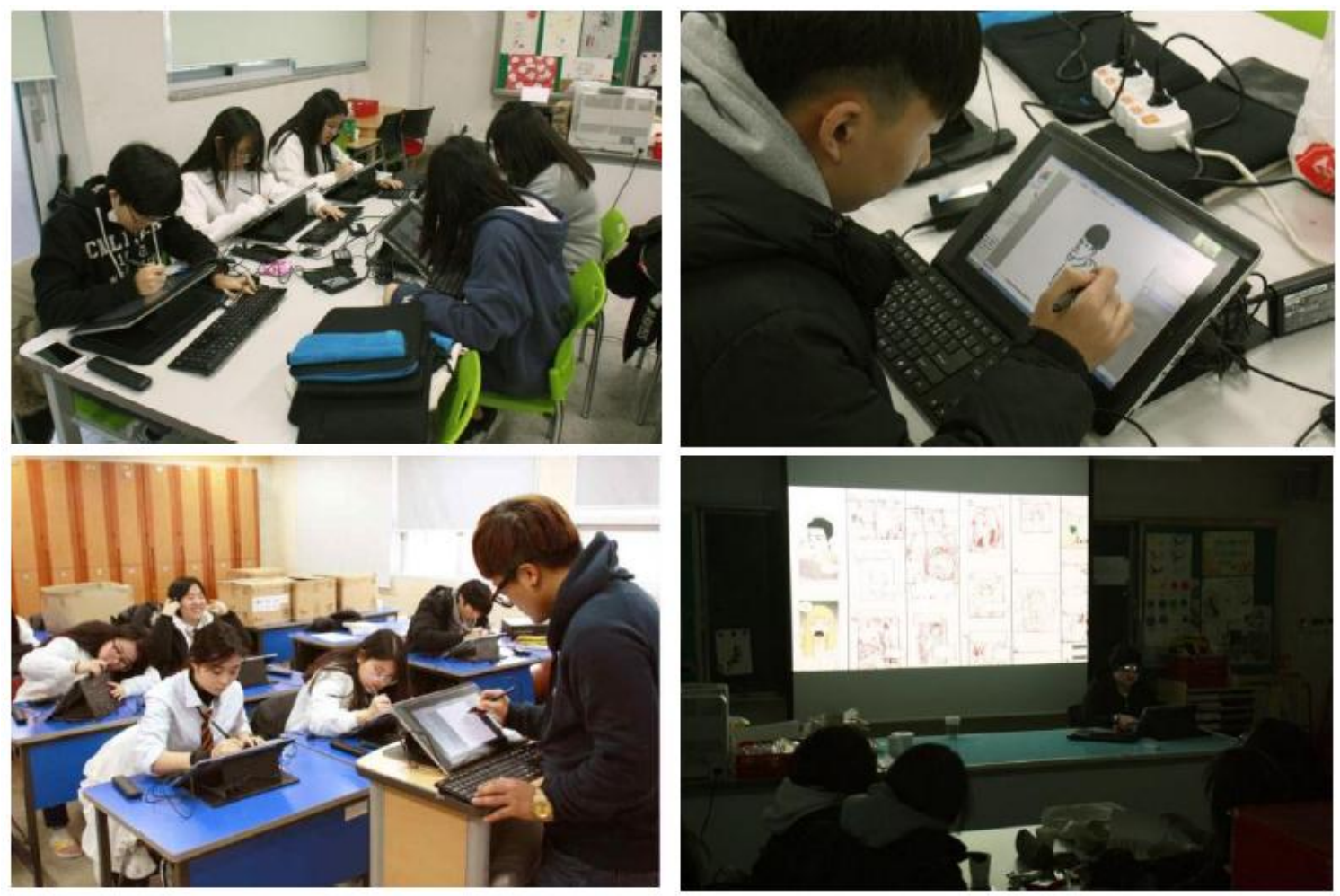

Figure 2. Manhwa Bus sessions with industry professionals for high school students residing in different communities in South Korea

The Manhwa Bus is a travelling bus equipped with all the toolkits and computers required for the program, and staffed by professional South Korean comic artists as well as college students majoring in cartoons and art. Each lesson is conducted by a different comic artist who shares tips, knowledge, and constructive feedback with aspiring teen artists. The Manhwa Bus team has taught approximately 837 students in 65 locations over the last 5 years (2014-2018). Their selection criteria include: (1) does the school have a comic club, and are participants members of the club? (2) is the school alienated from mainstream comics education, and have students had little opportunity to learn properly? (3) do students understand how comics are produced, and have they ever produced their own? and (4) do students display some talent or skill in creating comics?

The Manhwa Bus differs from outreach programs which run through the school's educational program in several ways. One distinctive feature of this program is that students who truly wish to learn about comics can proactively choose to apply for it. Unlike other programs, the Manhwa Bus is not intended for general individuals, but for a specific audience. Moreover, the team brings all the necessary equipment, such as computers and drawing tablets for the students. Students are therefore able to follow the entire comic production pipeline step by step without worrying about equipping themselves for the class.

The team created this service for both junior and senior high school students who have no opportunities to learn how to draw comics properly. They conduct the 5-6-hour session once a month and travel to different schools at any location upon request. This experience equips students with the basic skills required to create cultural content relevant to their society. All in all, this fulfills the criteria of experience-based learning found in Dewey's Philosophy of Progressive Education.

\section{Findings and Discussion}

We conducted group interviews after the completion of sixty-five programs. The findings of first-hand data indicated that nearly $98 \%$ (820 out of 837) of participants had highly positive feedback toward the program and its activities. Both tutors (industry professionals) and the participants (students) displayed a favorable attitude 
during the program, which connects aspiring young artists with professional artists. It presents art and cultural education to teenagers in a non-traditional format, merging the study of art with the teaching of tangible skills (comic drawing). Also, this experiential learning outreach program demonstrates the potential for students to develop their artistic skills under proper and continuous guidance. Therefore, outreach programs beyond the regular curriculum are necessary and should be encouraged through art and cultural organizations.

Key finding 1: Participants feel that having professional artists in their classroom is very effective for their learning

All participants comprised a mixture of junior high and high school comic club students who love to draw and read cartoons. The Manhwa Bus program selects famous and popular artists whose works are well recognized among the young participants. This connection increases the learning motivation and level of curiosity for students.

As one of participants wrote:

"It is unbelievable that we had an artist teacher who is a creator of this famous cartoon. The teacher did a very detailed demo session to show how we can draw various dynamic poses by applying proper human anatomy. In addition, she also taught us how to use the right color tone with the highlight function. The overall program was really practical, fun and helpful!"

Key finding 2: Providing opportunities with professional training and equipment can enable participants to be more confident and increase their involvement in art and cultural experience.

The valuable experience that students gain from this outreach program is the rare opportunity to reflect on their passion, talent, and motivation to achieve their potential with their artistic dreams. While the participants had not had any opportunities for professional training before, this outreach program-initiated participant-centric activities that sparked a strong sense of belonging to the comic community. The friendly learning environment and no-fee equipment for all participants allowed all students to feel compatibility and harmony during the program activity.

One of participants commented:

"I used to copy famous comic characters or try to mimic someone else's style. However, through the Manhwa Bus program, I finally got to learn how to develop my own style. I've always wanted to try high performance (but very expensive) drawing tablet myself, and then the Manhwa Bus organizing team provided the drawing tablets to all of us! We were super excited about using those awesome equipment for free and getting mentored by a famous comic artist. I feel privileged."

\section{Conclusion}

\section{Creating a model for cultural content outreach programs in Asia}

Taking into consideration the practices and beliefs behind Dewey's Philosophy of Progressive Education, as well as the challenges faced by alienated communities, this paper aims to create a model for cultural content outreach programs for alienated classes in Asia. Using South Korea as the geographical area of study, we note that while the country's cultural policy does place importance on traditional culture and the need for culture as a driver of identity politics, more work is needed to improve efforts at educating and reaching out to alienated communities.

Following our cross-regional study of outreach programs tailored to youths and individuals in alienated communities, and guided by Dewey's Philosophy of Progressive Education, we conclude that any cultural content outreach program in Asia requires four key ideas at its foundation (see Figure 3): (1) the need for outreach programs to be relevant and diffused into daily life; (2) the need and potential for experiential learning and varied experiences with relevant industries and mainstream communities; (3) the need to inculcate growth of thought and sharing of experiences with others within alienated communities; and (4) the need to educate and raise awareness of social consciousness.

We contend that rich cultural archives can be used effectively by providing varied content such as music, literature, and art to existing outreach programs to expand the educational limitations of museums and galleries. In addition, participants can enjoy cultural content as a part of life by experiencing the diversity and technology in the program's content. Finally, thanks to the expertise exchanged during the outreach program process, programs have the potential to remodel and restructure the experiences of those living in remote areas for continuous growth and development, ultimately enhancing their understanding of society. 


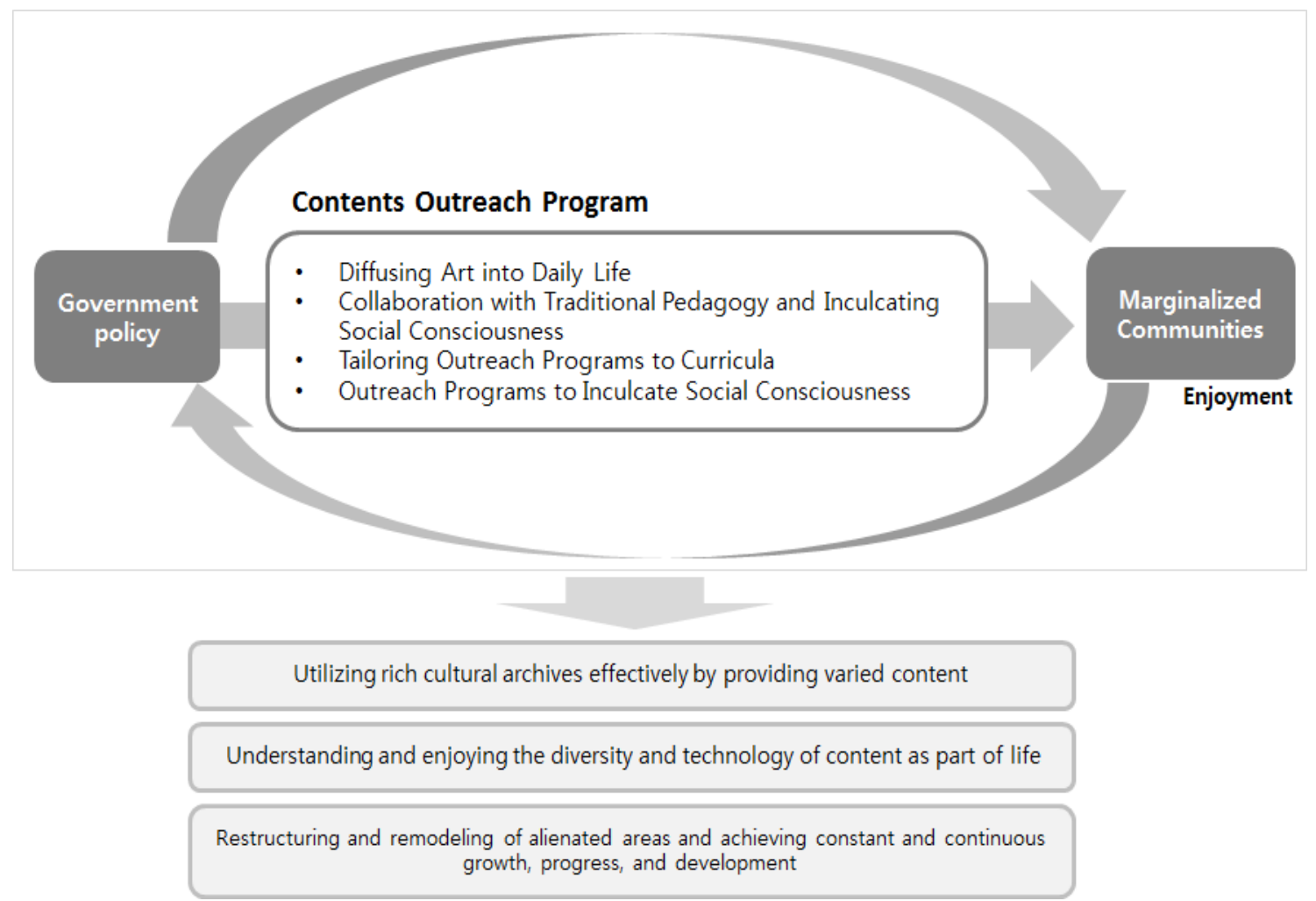

Figure 3. Model for Cultural Content Outreach Programs in Asia

\section{References}

Bradley, C. H. (1998). Mrs. Thatcher's cultural policies: 1979-1990: A comparative study of the globalized cultural system. Boulder, CO: Social Science Monographs.

Burgi-Golub, N. (2000). Cultural identity and political responsibility. International Journal of Cultural Policy, 7(2), 211-223. https://doi.org/10.1080/10286630009358143

Comaroff, J. L., \& Comaroff, J. (1992). Ethnography and the historical imagination. Boulder, CO: Westview Press.

Dewey, J. (1897). My pedagogic creed. School Journal, 54, 77-80.

Dewey, J. (1916). Democracy and education, Macmillan.

Dewey, J. (1956). The child and the curriculum. University of Chicago Press.

Elias, N. (1939). The civilizing process (1994 ed.). (E. Jephcott, Trans.). Hoboken, NJ: Blackwell.

Im, Han-Yeong. (1986). The life and philosophy of John Dewey. Seoul: BaeYoung Publications.

Johnson, R. (1986). What is cultural studies anyway?. Social Text, 16, 38. https://doi.org/10.2307/466285

Jung, Y. G. (2009). Ingan Ihaewa Gyoyukhak [Understanding Human and Pedagogy]. MunEumSa.

Kim, Y. (1976). Cultural policy in the Republic of Korea. Paris: Unesco.

Merry, S. E. (1998). Law, culture, and cultural appropriation. Yale Journal of Law \& the Humanities, 10(2), 575-603. Retrieved from http://digitalcommons.law.yale.edu/yjlh/vol10/iss2/16

Park, J. W. (2017). 4 Nyeonje Daehakgyo Yuagyoyukgwaui Gyogwa Gwajoeng Joon Munhwa Yesool Gyoyukui Hyunhwanggwa Gaeseone Gwanhan Yeongu [A study on the current status and improvement of cultural arts education in the 4th year university early childhood education curriculum - focused on metropolitan universities]. Journal of the Korean Academia-Industrial Cooperation Society, 18(1), 360-372. https://doi.org/10.5762/KAIS.2017.18.1.360

Pratt, M. L. (1992). Imperial eyes: Travel writing and transculturation. London, UK: Routledge. https://doi.org/10.4324/9780203163672 
Sandell, R. (2003). Social inclusion, the museum and the dynamics of sectoral change. Museum and Society, 1(1), 45-62.

Shin, S. H. (2007). Munhwa Yeshool Gyoukron Yeangu [A study on cultural-art pedagogy]. Korean Arts \& Cultural Education Service.

Vincent, J. (1990). Anthropology and politics: Visions, traditions, and trends. Tucson, AZ: University of Arizona Press.

Yim, H. (2002). Cultural identity and cultural policy in South Korea. International Journal of Cultural Policy, 8(1), 37-48. https://doi.org/10.1080/10286630290032422

Woo, S. H. (2005). Munhwa Yanguekhwa Haesoruel Wihan Jungchaek Jeok Jubguen [Political approach to resolve the cultural polarization]. Parliamentary Inspection of the Administration Policy Materials, National Assembly of Republic of Korea.

Zeller, T. (1989). The role of the humanities in art education. Art Education, 42(4), 48. https://doi.org/10.2307/3193143

Web References

Australian Museum. http://australianmuseum.net.au

The Fun Art Journey. http://lotteryarts.or.kr/index.lotteryarts?contentId=0

Manhwa Bus. http://blog.naver.com/manhwabus

Virginia MOCA. http://www.virginiamoca.org/outreach-details

Museums Victoria. http://museumsvictoria.com.au

\section{Copyrights}

Copyright for this article is retained by the author(s), with first publication rights granted to the journal.

This is an open-access article distributed under the terms and conditions of the Creative Commons Attribution license (http://creativecommons.org/licenses/by/4.0/). 